\title{
PUBLIC ADMINISTRATION AND STATE REGULATION IN THE CONTEXT OF LINGUISTIC RELATIONS
}

\section{Kryzhanovska Yevheniia ${ }^{1}$}

DOI: https://doi.org/10.30525/978-9934-571-89-3_52

At the end of the second decade of this century, the language question has not lost its relevance. It is constantly in the field of view of scientists, actively debating in political TV shows, social networks, the press, thereby testifying to his unresolved. The scientific works cover different views on this problem, consider the historical conditions that influenced the current linguistic situation, and analyze the policies of state bodies on a specific issue.

The transformation processes taking place in the system of linguistic relations are, to a certain extent, objective, since they are due to the world globalization, but this does not exclude government managing and control over them. Modern trends in the development of statehood and civil society make it necessary to revise the role of the state in managing public affairs, as well as the methods and means of its influence on social relations.

\footnotetext{
${ }^{1}$ Varna Free University "Chernorizets Hrabar", Bulgaria
} 
Research in recent decades has increasingly highlighted the cardinal changes in approaches to the issue of governance of public processes by the state, the study of modern European and world experience of public administration. Among their authors: N.I. Baldich, D.Kh. Bekkaliev, M.P. Berliozov, Krzysztof Białobłocki, V.G. Bodrov, M.Yu. Varfolomeeva, V.N. Vinogradova, A.V. Vostrikov, N.S. Grishkova, L.E. Kalinina, M.S. Koltyshev, O.M. Mogilny, Nabiev Samir Adil Ogly, S.N. Naumenko, V.E. Negodov, O.M. Safronova, A.V. Serebrennikov, T.O. Shiluk, Harmut Shnider, E.N. Scherbak and other.

The starting point of these studies is the very definition of the concept of "public administration". Traditionally, it refers to the organizing, executive and administrative activities of state bodies, local self-government bodies, public and other non-state formations, endowed with relevant state and authority, carried out on the basis of law and other regulatory acts [3, p. 1270].

The issue of public administration of society has deep historical roots. This problem was examined in the writings of ancient philosophers (Plato, Aristotle), thinkers of the Renaissance and Enlightenment (N. Machiavelli, S. Montesquieu, J. Rousseau, D. Diderot), the English materialist T. Hobbs and others [6, p. 43-50, 171, 398, 441-442, 539-543, 621-622, 850-853]. German scientists I. Kant and R. Mol developed questions of the constitutional state. The classics of MarxismLeninism viewed the state as a political organization of the economically dominant class. In the Russian pre-revolutionary historical science, progressive figures (V.P. Bezobrazov, A.D. Gradovsky, B.N. Chicherin) sought to build an optimal structure for the local organization, to offer effective options for the relationship between state and local structures, which resulted in two theories of self-government: public and state. In the philosophical literature of the twentieth century, management is analyzed from the essential self-governing properties of society point of view (K. Popper, B. Russell, K. Jaspers). Positions and conclusions of philosophical thought created the worldview and methodological basis of scientific knowledge and practical improvement of management, which contributed to the orientation of creative searches. The historical aspect of management contains tremendous theoretical and practical knowledge, since it allows to see the place and role of management in various types of human civilization and in solving a wide variety of social, religious and national problems (N.M. Karamzin, M.M. Mikhailovsky, S.M. Soloviev, A.J. Toynbee) [6, p. 287-292, 553, 620-621, 622-625, 737, 772-774, 895-896].

In the 70s of the twentieth century, public administration begins to develop in two directions: first, as an independent direction within the general theory of social management (V.G. Afanasyev, Yu.P. Averin, V.S. Osnovin, and others); the second as production management, which brought together researchers and practitioners, academic and university science specialties in Economics and Management. The synthesis of economic and technological knowledge, carried out by Western progressive figures F. Taylor, A. Fayol, H. Ford, H. Emerson, led to the formation of a system of knowledge, called the "management theory" [5, p. 38, 41, 44, 45]. The result of the rapid changes that occurred in the society of the former Soviet republics 
and the newly formed independent states in the late 80s - early 90s of the XX century was a change of ownership of the production's means and, as a result, a sharp change in the nature of relations in the sphere of production, distribution and consumption of goods and services. These changes led not only to the abolition of the state monopoly on many types of activities and changes in the fundamentals of the economy, but also to a fundamental restructuring of the foundations of society that had been formed during the seventy-year Soviet historical period.

The result of the development of the tendencies under consideration and the response to the spontaneous changes in state construction of the early 1990s was the strengthening of the position of state regulation institution and its widespread use as the main instrument for influencing social relations in the vast majority of business areas.

Numerous publications by legal-scientists, economists, and specialists in public administration (V.B. Averyanov, E.G. Antonova, I.F. Ilnitskaya, A.V. Perfilyev, M.P. Tkach and others) are devoted to the issues of the ratio between the concepts of "public administration" and "government regulation".

Under the state, as well as any other type of management, imply the guiding influence of the subject of management (governing system) on the object of management (managed system). Characteristic features of public administration is the subordination of the object of management (which at the same time is a completely independent participant in legal relations and the subject of state authority) to the subject of management, represented by the executive authorities, officials, employees, authorized non-state actors.

State regulation, according to a number of scientists, is a notion narrower than state administration [1, p. 64-65; 4, p. 96-97]. It can be defined as a set of tools with which the state establishes requirements for organizations and citizens. It includes laws, formal and informal regulations and subsidiary rules, which are established by the state, as well as by non-governmental or self-regulatory organizations, to which the state has delegated regulatory authority. Sometimes regulation is considered as one of the management functions (V.B. Averyanov), due to the theoretical uncertainty of the relationship between these concepts.

It is more expedient to evaluate the similarities and differences between the concepts of "regulation" and "management" in the context of not only their interrelations, but also the general notions of "organization" and "organizational activity" [2, p. 1005]. Especially it concerns the use of these terms in relation to language policy and transformation processes that occur in it at the present time in the world space.

In modern scientific literature, the term "organization" in the sense of "organizational activity" (including the organization of the process of implementing language policy, transformation, etc.) is considered to be more extensive regarding the concepts of "regulation" and "management". These concepts are considered as types of organizational activity that have common features that reveal the essence of these concepts through recognition of the nature of organizational influence on certain public objects. 
Thus, "state management" and "state regulation" reflect various forms of manifestation and stages of organizational activity, which ensures the orderliness of social objects and the organization of purposeful influence on them. Based on the general concepts of the relationship between the fundamental concepts of management science, it is possible to comprehend the concept of "state regulation of language policy". It should be determined based on the general management theory, taking into account the specific field of activity of state executive bodies. Consequently, the "government regulation" is a broader concept than the "public administration", as it covers a wide scope of organizational activities of the state.

\section{References:}

1. Averjanov V. B. (2004). Administratyvne pravo Ukrajiny [Administrative law of Ukraine]. Kyiv: Yurydychna dumka. (in Ukrainian)

2. Andreichyn L., Heorhyev L., Ylyev St., Kostov N., Lekov Yv., Stoikov St., Todorov Tsv. (2002). Bŭlgarski tŭlkoven rechnik - Chetvŭrto izdanie. Dopŭlneno i preraboteno ot Dimitŭr Popov [Bulgarian interpretive vocabulary - Fourth edition. Supplemented and processed by Dimitar Popov]. Sofia: Nauka i izkustvo. (in Bulgarian)

3. Antonova I., Gaberov I., Pavlov P., Grozev A., Sprostranov T., Rozov E., Mladenova M., Volgin P., Tsvetkova M., Arnaudov B., Petrov B., Velikova M., Gŭlova D., (2001-2002). Bŭlgarski entsiklopedichen rechnik. 77000 statii ot poznanieto / po ideya i s redaktsiite na Ivan Gaberov. Vtoro preraboteno i dopŭlneno izdanie [Bulgarian encyclopedic dictionary. 77000 articles of knowledge / ideas and edits by Ivan Gaberov. Second revised and edited edition]. V. Tŭrnovo: AD "Abagar". (in Bulgarian)

4. Omelchenko A. V. (2011). Administratyvno-pravovi zasady zovnishno-ekonomichnoi diialnosti v Ukraini: monohrafiia [Administrative and legal principles of foreign economic activity in Ukraine: monograph]. Kyiv: KNEU. (in Ukrainian)

5. Serafymova D. (2010). Teoriya na upravlenieto - Vtoro preraboteno i dopŭlneno izdanie [Theory of Management - Second revised and supplemented edition]. Varna: STENO. (in Bulgarian)

6. Stoychev V. (2009). Filosofski rechnik. Cambridge [Philosophical Dictionary. Cambridge] (The Cambridge Dictionary of Philosophy, Edited by Robert Audi. Cambridge University Press, The Press Syndicate of the University of Cambridge. Cambridge 1995) / Prevod. Izdanieto otrazyava sŭbiti i fakti kŭm m. avgust 2009. [Translation. The release reflects events and facts by August 2009]. Sofia: Trud. (in Bulgarian) 